\title{
DEVER DE FUNDAMENTAÇÃO DAS DECISÕES JUDICIAIS (EXEGESE DO ARTIGO 489, § 1º, DO CÓDIGO DE PROCESSO CIVIL DE 2015) ${ }^{1}$
}

\author{
DUTY OF THE FOUNDATION OF JUDICIAL DECISIONS (EXEMPT FROM \\ ARTICLE 489, § 1, OF THE CODE OF CIVIL PROCEDURE OF 2015)
}

Eduardo Cambi Mestre e Doutor em Direito pela Universidade Federal do Paraná (UFPR). Pós-doutor pela Univesità degli studi di Pavia. Professor da Universidade Estadual do Norte do Paraná (UENP) e da Universidade Paranaense (UNIPAR). Promotor de Justiça no Estado do Paraná. Assessor da ProcuradoriaGeral de Justiça. Coordenador do Centro de Estudos e Aperfeiçoamento Funcional (CEAF) do Ministério Público do Paraná. Membro da Academia Paranaense de Letras Jurídicas. Curitiba/PR. E-mail: eascambi@mppr.mp.br

Marcos Vinícius Tombini Munaro Mestre em Direito processual civil e cidadania pela UNIPAR (Universidade Paranaense). Especialista em Direito aplicado pela EMAP (Escola da Magistratura do Estado do Paraná). Pós-graduado em Direito Civil e Processo Civil pela Faculdade de Ciências Sociais e Aplicadas de Cascavel. Especialista em Direito Público pela Universidade AnhangueraUniderp. Professor do curso de graduação em Direito no Centro Universitário da FAG (Fundação Assis Gurgacz). Advogado e consultor jurídico. Curitiba/PR. E-mail: marcosmunaro@hotmail.com

\footnotetext{
${ }^{1}$ Artigo recebido em 14/04/2019 e aprovado em 04/08/2019.
} 
RESUMO: O presente artigo se propõe a abordar o dever de fundamentação das decisões judiciais com as inovações trazidas pelo Código de Processo Civil de 2015, já que ele considera não fundamentadas as decisões judiciais enquadradas no artigo $489, \S 1^{\circ}$.

PALAVRAS-CHAVE: fundamentação - decisão judicial - Código de Processo Civil de 2015 - artigo $489, \S 1^{\circ}$, do CPC/2015.

ABSTRACT: The present article proposes to approach the reasoning of judicial decisions and the necessity of paradigm change with the entry of the Code of Civil Procedure of 2015, in particular because it considers the judicial decisions framed in article $489,1^{\circ}$.

KEYWORDS: justification - judicial decisions - Code of Civil Procedure of 2015 - article 489, paragraph 1, of CPC/2015.

SUMÁRIO: - 1. Introdução - 2. Motivação e fundamentação das decisões judiciais - 3. Justificação das decisões judiciais: dever constitucional da motivação - 4. A evolução do dever de fundamentação das decisões judiciais: o artigo 489, §1. ${ }^{\circ}$, do CPC/2015 e os parâmetros mínimos da motivação judicial - 4.1. Análise do Inciso I, §1 ${ }^{\circ}$, do artigo 489 - 4.2. Interpretação do Inciso II, $\S 1^{\circ}$, do artigo 489 - 4.3. Exegese do Inciso III, $\S 1^{\circ}$, do artigo 489 - 4.4. Exame do Inciso IV, $\S 1^{\circ}$, do artigo 489 - 4.5. Análise do Inciso V, § $1^{\circ}$, do artigo 489 - 4.6. Interpretação do Inciso VI, §1º do artigo 489 - Decisões judiciais embargáveis: A relação do artigo 489, § 1. ${ }^{\circ}$ com os artigos 1.022 do CPC/2015 e 93, inciso IX, da CF/88. 6. Conclusão - 7. Bibliografia.

\section{Introdução}

A Lei $\mathrm{n}^{\circ}$ 13.105, de 16 de março de 2015, trouxe impactos significativos ao processo civil e ao ordenamento jurídico brasileiro e exigirá mudanças na atuação dos sujeitos processuais, por não considerar fundamentadas as decisões judiciais nas hipóteses previstas no artigo $489, \S 1^{\circ}$.

O texto abordará os artigos 489, $\S 1^{\circ}$ e 1.022 do novo Código de Processo Civil, juntamente com o artigo 93, inciso IX, da Constituição Federal de 1988, com o intuito de defender a necessidade de fundamentação das decisões judiciais, principalmente para combater aquelas 
que, sob o viés do legislador, não são fundamentadas.

O artigo 489, $\S 1^{\circ}$, do Código de Processo Civil trouxe um rol de situações nas quais a decisão interlocutória, a sentença, ou o acórdão não serão considerados fundamentados. E, caso tal situação ocorra, poderá a parte prejudicada interpor embargos de declaração, sem o risco de os mesmos serem considerados protelatórios, pois o artigo 1022, parágrafo único, inciso II, versa sobre essa hipótese de omissão.

Por isso, é importante analisar: a) o conceito de fundamentação e quando considerar fundamentada uma decisão judicial; b) os pontos para se alcançar a fundamentação nas decisões judiciais e a sua consequente validade, sob o viés do novo CPC; c) os entendimentos dos tribunais, em especial do Superior Tribunal de Justiça, negando vigência ao artigo 489, parágrafo primeiro, do Código de Processo Civil de 2015; d) formas processuais de combater os atos judiciais afrontadores do artigo 489, $\S 1^{\circ}$, do Código de Processo Civil de 2015; e) o artigo 489, $\S 1^{\circ}$ e do 1.022, ambos do Código de Processo Civil de 2015, em conjunto com o artigo 93, inciso IX, da Constituição Federal da República Federativa do Brasil.

Ainda, será questionada a negativa dos julgadores de não respeitarem o artigo 489, § $1^{\text {o }}$, do Código de Processo Civil de 2015. Além disso, serão expostos os mecanismos, seja na seara legal, seja na seara constitucional, necessários para combater tal prática, alicerçando-se no artigo 93, inciso IX, da Constituição Federal.

\section{Motivação e fundamentação das decisões judiciais}

A maioria dos ordenamentos jurídicos mundiais impõem o dever de motivação das decisões judiciais. Por exemplo, na Itália, tal dever está inserido no artigo 111 comma 6, da Constituição. O juiz tem o dever de justificar a sua decisão, expondo as razões de validade e racionalidade ${ }^{2}$.

No Brasil, a Constituição Federal dispõe de forma clara que toda decisão judicial deve ser fundamentada, em atenção ao contido no artigo 93, inciso IX, da CF/88, pois todos os julgamentos dos órgãos do Poder Judiciário devem ser públicos, com a devida fundamentação de todas as decisões judiciais, sob pena de nulidade, respeitadas as

2 TARUFFO, Michele. Uma simples verdade: O juiz e a construção dos fatos. Tradução Vitor de Paula Ramos. São Paulo: Marcial Pons, 2016. p. 271. 
exceções legais de preservação do direito à intimidade do interessado, desde que o sigilo não prejudique o interesse público à informação ${ }^{3}$.

De início, é importante destacar a diferença entre motivação e fundamentação, que embora sejam fruto de um mesmo objeto, apresentam nuances diferenciadas. O juiz oferece os motivos da decisão, na qual podem ocorrer discussões sobre a forma de origem da sua convicção. Tecnicamente, motivação é a discussão dos motivos e a fundamentação é o resultado final; ou seja, a fundamentação é a análise final dos motivos apreciados no processo ${ }^{4}$.

A fundamentação das decisões judiciais - o que inclui a motivação - mais do que uma simples exigência do Estado Democrático de Direito, se trata de um direito fundamental do cidadão. As decisões judicias devem estar justificadas com razões e argumentos jurídicos, e servem para evitar julgamentos arbitrários. A motivação está vinculada aos direitos dos cidadãos de obterem o provimento à tutela judicial efetiva. Tamanha é sua importância que o TEDH (Tribunal Europeu de Direitos Humanos) considera a motivação como um direito fundamental a um processo equitativo.

As decisões judiciais necessitam indicar de forma suficiente os motivos em que se fundam. Logo, a fundamentação é garantia para as partes, que podem se convencer das suas razões, ou permitir a sua revisão, se necessário e possível, em instância superior ${ }^{5}$. O devido esclarecimento por parte do julgador é ponto demasiadamente fundamental para possibilitar as partes o direito de recorrer ${ }^{6}$.

É exigência constitucional que os atos jurisdicionais, sejam motivados, sob pena de nulidade (art. 93, IX, da CF/88), especialmente para se realizar o controle político e social da função jurisdicional. A existência de motivação decorre da preservação dos interesses públicos e particulares. Serve para detectar a imparcialidade do juiz e a justiça de suas decisões, conformando os envolvidos das razões de convencimento. Decisão não motivada

3 BRASIL. Constituição (1988). Constituição da República Federativa do Brasil. Diário Oficial [da] República Federativa do Brasil, Brasília, DF, 05 out. 1988. Disponível em: <http://www.planalto.gov.br/ccivil_03/constituicao/constituicao.htm>. Acesso em: 29 mar. 2017.

$4 \quad$ AMARAl SANTOS, Moacyr. Primeiras Linhas de Direito Processual Civil. 3. vol. 4a. ed. São Paulo: Max Limonad, 1973. p. 42.

5 CANOTILHO. José Joaquim Gomes. et al. (Coord.). Comentários à Constituição do Brasil. São Paulo: Almedina, 2013. p. 1324.

6 ARAÚJO, Fábio Caldas de. Curso de Processo Civil: parte geral. São Paulo: Malheiros, 2016. p. 164. 
Revista Eletrônica de Direito Processual - REDP.

Rio de Janeiro. Ano 13. Volume 20. Número 2. Maio a Agosto de 2019

Periódico Quadrimestral da Pós-Graduação Stricto Sensu em Direito Processual da UERJ

Patrono: José Carlos Barbosa Moreira (in mem.). ISSN 1982-7636. pp. 125-158

www.redp.uerj.br

é nula, tratando-se de matéria de ordem pública, admitindo-se arguição em qualquer instância ${ }^{7}$.

Interessante destacar que normalmente a Constituição Federal não apresenta normas sancionadoras, sendo, geralmente principiológica e descritiva, afirmando direitos e deveres. Mas, a falta de motivação é vício de extrema gravidade que o constituinte inseriu no próprio texto constitucional a pena de nulidade ${ }^{8}$.

O dever de motivação das decisões judiciais integra a cláusula do devido processo legal e, ainda que não houvesse expressa previsão legal, poderia ser extraído do art. $5^{\circ}$, inciso LI, da Constituição da República ${ }^{9}$.

Para uma decisão judicial ser considerada motivada, há de observar dois aspectos: 1) o enunciado das escolhas do julgador precisa atender a individualização das normas aplicáveis, com rigoroso exame dos fatos e do enquadramento jurídico para aquela situação, de modo previsível para as consequências jurídicas decorrentes dessa subsunção do fato à norma; 2) o órgão jurisdicional deve buscar o nexo de causalidade entre o fato e a sua regular inclusão normativa ${ }^{10}$.

O novo Código de Processo Civil reforçou o dever constitucional de motivação das decisões judiciais no artigo $489, \S 1^{\circ}$, ao traçar um rol exemplificativo ${ }^{11}$ de situações em que $\mathrm{o}$ ato judicial será considerado não fundamentado. $\mathrm{O}$ ordenamento processual brasileiro não admite decisões implícitas, pois elas devem ser fundamentadas de forma suficiente, enfrentando todas as questões fáticas e jurídicas relevantes ${ }^{12}$. Afinal, o não cumprimento do dever de motivação contraria o Estado Democrático de Direito, já que apenas nos regimes autoritários não se pode fazer uso das razões e decide-se de forma obscura, sem expor a maneira de se atingir o convencimento judicial ${ }^{13}$.

7 DONIZETTI, Elpídio. Curso didático de direito processo civil. 17a. ed. São Paulo: Atlas, 2013. p. 98.

8 NERY JÚNIOR. Nelson. Princípios do processo civil na Constituição Federal. 7a. ed. São Paulo: Revista dos Tribunais, 2002. p. 184.

9 BULOS, Uadi Lammêgo. Constituição Federal anotada. 10a. ed. São Paulo: Saraiva, 2012. p. 1013-1014.

10 Idem. p. 1014.

11 MARCACINI. Augusto Tavares Rosa. As inovações do CPC/2015. Da propositura da ação até a sentença. São Paulo: A. Marcacini, 2016. p. 92.

12 RODRIGUES WAMBIER Luiz; TALAMINI Eduardo. Curso Avançado de Processo Civil. v.1. 13a ed. São Paulo: Revista dos Tribunais, 2013. p. 71-72.

13 MOTTA, Cristina Reindolff da. A motivação das decisões cíveis como condição de possibilidade para a resposta correta/adequada. Porto Alegre: Livraria do Advogado Editora, 2012. p. 78. 
Com efeito, exige-se que o juiz motive racionalmente as suas decisões, combatendo toda e qualquer decisão baseada na íntima convicção (art. 93, IX, da CF/88). Motivação correta e adequada constrói-se a partir de argumentos racionais, que servem para o julgador convencer as partes ou justificar a elas o seu acerto. Além disso, o órgão jurisdicional deve evitar realizar apenas a valoração positiva das provas, porque, além de mencionar os argumentos do seu convencimento, há de explicar por que as demais provas foram insuficientes para lhe persuadir (valoração negativa das provas). Caso contrário incorre no confirmation bias (distorção sistemática do próprio raciocínio), típico de órgãos judiciários que, ao confirmarem uma valoração, selecionam apenas os argumentos disponíveis dentre os favoráveis e descartam os contrários, sem fazer uma análise aprofundada destes ${ }^{14}$.

O Tribunal Constitucional espanhol já deliberou que, ao se omitir o raciocínio em relação a alguma das pretensões, não há como se defender que a decisão judicial está fundada no Direito. Portanto, o dever de motivação serve: a) como garantia contra o arbítrio; b) como garantia contra a influência de pontos de vista subjetivos; c) para os litigantes e interessados obterem conhecimento sobre os fundamentos da decisão e, se necessário, para que possam formular recurso da decisão; d) para gerar maior previsibilidade e segurança jurídica ${ }^{15}$.

O dever de fundamentação das decisões judiciais é um elemento fundamental do Estado Democrático de Direito, pois é a melhor forma de legitimação da decisão do Estado-Juiz. A formação da decisão está calcada na integridade e na coerência, materializada na cadeia de normas envolventes da atuação judiciária. Fundamentar é, destarte, mais do que uma formalidade jurídica, um direito fundamental do cidadão ${ }^{16}$.

\section{Justificação das decisões judiciais: dever constitucional da motivação}

Do mesmo modo que existe o dever fundamental de justificar as decisões, existe o direito fundamental à obtenção de respostas corretas e adequadas à Constituição. Há uma ligação umbilical entre o dever fundamental a esse direito fundamental. Ambos se complementam e representam uma blindagem contra interpretações deslegitimadoras e

14 CAMBI, Eduardo. Neoconstitucionalismo e neoprocessualismo: Direitos fundamentais, políticas públicas e protagonismo judiciário. 2a. ed. São Paulo: Almedina, 2018. p. 423-435.

15 Idem, p. 436.

16 CANOTILHO. José Joaquim Gomes. et al. (Coord.). Op. cit., p. 1325. 
Revista Eletrônica de Direito Processual - REDP.

Rio de Janeiro. Ano 13. Volume 20. Número 2. Maio a Agosto de 2019

Periódico Quadrimestral da Pós-Graduação Stricto Sensu em Direito Processual da UERJ

Patrono: José Carlos Barbosa Moreira (in mem.). ISSN 1982-7636. pp. 125-158

www.redp.uerj.br

despistadoras do conteúdo que sustenta o domínio normativo dos textos constitucionais ${ }^{17}$.

Os temas principais da causa devem ser justificados, isto é, devem ser explicitadas as razões para sustentar a racionalidade dos argumentos como verdadeiros ${ }^{18}$.

A completa motivação implica que haja uma justificativa adequada para os pontos principais invocados pelas partes no processo. Em outros termos, todo enunciado considerado verdadeiro pelo juízo deve ser confirmado pelas interferências probatórias, das quais representa a conclusão; e igual entendimento vale para a falsidade das provas, já que mesmo falsos, resultam em interferências na seara probatória. Ademais, para se atingir a completude da motivação, o julgador deve valorar e respeitar as provas, pois elas servem para confirmar os seus enunciados ${ }^{19}$.

A capacidade de decisão é situação deveras importante na vida do Estado, assimilando-se, entre os cientistas da política, como o próprio conceito de poder político: decidir imperativamente e impor decisões. Nota-se, na atividade estatal, a presença maciça das decisões, para a consecução dos objetivos programados, mas, da mesma forma, é de se ter em mente que decisões sem condições de efetividade não são aptas para alterar a realidade, não revelando a presença do poder da jurisdição ${ }^{20}$.

Justificar as decisões judiciais é um imperativo constitucional. Consiste na

17 STRECK. Lenio Luiz. Verdade e consenso. Constituição, hermenêutica e teorias discursivas. 6 a. ed. São Paulo: Saraiva, 2017. p. 687-688.

18 "Em outros termos: devem ser indicadas as interferências probatórias que atribuem graus adequados de confirmação a esses enunciados. Isso leva a que se exclua, em particular, no que diz respeito ao juízo sobre os fatos, a difundida concepção segundo a qual a motivação não seria outra coisa senão um discurso retórico-persuasivo, tendo o fim não de justificar racionalmente a decisão, mas sim de convencer alguém a aceita-la. Essa concepção parece, todavia, excessivamente redutiva e substancialmente inaceitável: o juiz, ao motivar, não deve persuadir pessoa alguma; ao invés disso, deve fornecer as razões pelas quais sua decisão pode parecer fundada diante de um controle intersubjetivo de validade e confiabilidade. Em particular, no que diz respeito à motivação dos fatos, essa não visa a criar na mente de alguém um status psicológico correspondente à crença subjetiva (à persuasão) de que os fatos são verdadeiros. A motivação deve indicar as razões pelas quais o juiz entendeu que os fatos resultaram provados com base nas quais justifica a sua decisão, fazendo referência às provas; não é para que creia na veracidade daqueles fatos. Naturalmente, nada exclui que a motivação da sentença, sendo um discurso formulado na linguagem comum e não em linguagem formal, contenha também aspectos, passagens, argumentos e referências de caráter teórico, que possam ser acrescentados ad colorandum, ou na tentativa de tornar mais simples o discurso. Esses elementos são, entretanto, substancialmente supérfluos e - sobretudo - inidôneos a colimar eventuais lacunas da argumentação justificativa desenvolvida pelo juiz” (TARUFFO, Michele. Op. cit. p. 273).

19 Idem. p. 275.

20 DINAMARCO, Cândido Rangel. A instrumentalidade do processo. 12a. ed. São Paulo: Malheiros Editores, 2005. p. 106-108. 
manifestação clara e ordenada de razões existentes no ordenamento jurídico, suficientes para dar justificação para a decisão judicial ${ }^{21}$. Cabe à jurisdição constitucional preservar a independência e a conservação da coexistência das forcas políticas diferentes, fazendo a Constituição ganhar vida, sendo o respeito a essa condição fundamento de sua própria eficácia ${ }^{22}$.

Para se falar em motivação adequada, necessita-se inserir justificações suficientes sobre o direito e o fato, com bons argumentos, para todos valorarem, posteriormente, as razões de formação do convencimento judicial. Os argumentos, como afirma Robert Alexy, seriam a expressão pública da reflexão. A correta decisão deriva da racionalidade da argumentação jurídica, com distinção entre justificação interna e externa. A primeira disciplina a regra e a autoridade de competência da interpretação. A segunda remonta a postulados tradicionais da teoria do silogismo jurídico. Correção, sob este contexto, significa a aceitabilidade racional da decisão, amparada em um discurso jurídico desenvolvido de forma argumentativa. Com efeito, sobressaem dois aspectos importantes para uma correta decisão: 1) a justificativa deve ser baseada em uma ordem jurídica formalmente válida; 2) o direito formalmente válido e considerado deve ser racional ou justo $^{23}$.

Aliás, o discurso jurídico, assim como o discurso prático geral, preocupa-se com a correção de afirmações; só que o primeiro recai sobre questões práticas desenvolvidas no processo, estando a argumentação restrita às leis, aos precedentes judiciais, à dogmática jurídica, entre outras limitações e regras de ordem processual. Embora não seja algo infalível, o discurso jurídico possui critérios de discussão e julgamento, amparados em critérios racionais sobre direitos. A Constituição não permite que todos os desejos sejam transformados em realidade. Contudo, serve como texto que vincula os juízes, pois estes devem fundamentar as decisões baseados em standards jurídicos objetivos, sem arbitrariedades e sem a possibilidade de se colocarem no lugar dos legisladores ${ }^{24}$.

A decisão do julgador, para atingir a motivação adequada, deve ser coerente e

21 CUNHA, José Sebastião Fagundes (Coord. geral); BOCHENEK, Antonio Cesar; CAMBI, Eduardo (Coord). Código de Processo Civil comentado. São Paulo: Revista dos Tribunais, 2016. p. 288.

22 HESSE, Konrad. Elementos de Direito Constitucional da República Federal da Alemanha. Tradução de Luís Afonso Heck. 20. ed. Porto Alegre: Sérgio Antônio Fabris Editor, 1998. p. 419.

23 CAMBI, Eduardo. Op. cit., p. 448-454.

24 Idem, p. 455-458. 
Revista Eletrônica de Direito Processual - REDP.

Rio de Janeiro. Ano 13. Volume 20. Número 2. Maio a Agosto de 2019

Periódico Quadrimestral da Pós-Graduação Stricto Sensu em Direito Processual da UERJ

Patrono: José Carlos Barbosa Moreira (in mem.). ISSN 1982-7636. pp. 125-158

www.redp.uerj.br

congruente, em harmonia com os fatos. De nada adianta um conjunto caótico de argumentos e enunciados desconexos e contraditórios, pois estes não desempenham papel de justificação. Se a motivação fática existir de forma efetiva, for completa e coerente, poder-se-á dizer que os detalhamentos dos fatos construídos pelo juiz possuem uma justificativa racional válida, já que confirmada por uma análise crítica de todas as provas disponíveis ${ }^{25}$.

Além disso, o legislador não precisa de autorização para desempenhar a sua tarefa de trazer as normatividades jurídicas para o seio da sociedade, desde que desempenhe a tarefa dentro dos quadros de competência previstos na Constituição. Ressalta-se que o Legislativo é o único órgão nato e natural da atividade legiferante destinada a dar aplicabilidade aos preceitos constitucionais ${ }^{26}$.

Portanto, o julgador deve evidenciar as razões de fato e direito, para justificar uma decisão, seguindo um raciocínio lógico, direto, explicativo e convincente da postura adotada, não se admitindo a motivação implícita, sob pena de nulidade. $\mathrm{O}$ requisito constitucional só será satisfeito com análise dos argumentos e demais elementos de prova constantes no processo ${ }^{27}$.

\section{A evolução do dever de fundamentação das decisões judiciais: o artigo 489, §1 $^{\circ}$ do CPC/2015 e os parâmetros mínimos da decisão judicial}

Uma das principais novidades do Código de Processo Civil de 2015 é o $§ 1^{\circ}$, do artigo $489^{28}$, uma vez que, caso o julgador não preencha todos os requisitos dos incisos I, II e III,

25 TARUFFO, Michele. Op. cit., p. 277-278.

26 CANOTILHO. José Joaquim Gomes. Constituição Dirigente e Vinculação do Legislador. Coimbra: Coimbra, 2001. p. 217.

27 BULOS, Uadi Lammêgo. Op. cit., p. 1013.

28 “Art. 489. São elementos essenciais da sentença: I - o relatório, que conterá os nomes das partes, a identificação do caso, com a suma do pedido e da contestação, e o registro das principais ocorrências havidas no andamento do processo; II - os fundamentos, em que o juiz analisará as questões de fato e de direito; III o dispositivo, em que o juiz resolverá as questões principais que as partes lhe submeterem. $\S 1^{\circ}$ Não se considera fundamentada qualquer decisão judicial, seja ela interlocutória, sentença ou acórdão, que: I - se limitar à indicação, à reprodução ou à paráfrase de ato normativo, sem explicar sua relação com a causa ou a questão decidida; II - empregar conceitos jurídicos indeterminados, sem explicar o motivo concreto de sua incidência no caso; III - invocar motivos que se prestariam a justificar qualquer outra decisão; IV - não enfrentar todos os argumentos deduzidos no processo capazes de, em tese, infirmar a conclusão adotada pelo julgador; V - se limitar a invocar precedente ou enunciado de súmula, sem identificar seus fundamentos determinantes nem demonstrar que o caso sob julgamento se ajusta àqueles fundamentos; VI - deixar de seguir enunciado de súmula, jurisprudência ou precedente invocado pela parte, sem demonstrar a existência de distinção no caso 
Revista Eletrônica de Direito Processual - REDP.

Rio de Janeiro. Ano 13. Volume 20. Número 2. Maio a Agosto de 2019

Periódico Quadrimestral da Pós-Graduação Stricto Sensu em Direito Processual da UERJ

Patrono: José Carlos Barbosa Moreira (in mem.). ISSN 1982-7636. pp. 125-158

www.redp.uerj.br

bem como, se incorrer em uma das hipóteses descritas nos incisos I, II, III, IV, V ou VI, do

$\S 1^{\circ}$, não se está diante de ato jurídico válido no ordenamento. Tal nulidade pode ser reconhecida de ofício ou por provocação das partes.

Por outro lado, o $\S 1^{\circ}$ do artigo 489 do Novo CPC é um dos dispositivos mais polêmicos do ordenamento processual, desde o anteprojeto até a publicação do Código. A resistência legislativa, à época do projeto, por causa deste dispositivo, deu a alcunha de $o$ Código da Fundamentação, levando em conta a vasta importância desta norma jurídica ${ }^{29}$.

Importante frisar que o $\S 1^{\circ}$ do dispositivo em comento apresenta um rol exemplificativo, decorrente da própria concretização do dever fundamental da motivação das decisões judiciais ${ }^{30}$. Ademais, não obstante o artigo 489 tratar em seu caput dos requisitos essenciais da sentença, nota-se, na redação do seu parágrafo $1^{\circ}$, que o legislador estendeu as hipóteses dos incisos I a VI tanto para as sentenças, como para as decisões interlocutórias e acórdãos.

O dispositivo sob exame mostra que o Novo Código não busca a todo e qualquer custo a celeridade processual, preocupando-se, também, em melhorar a qualidade da prestação jurisdicional, impondo sanção de nulidade, com a penalidade de considerar não fundamentada a prestação jurisdicional na hipótese de se incorrer em alguma das situações contidas nos incisos do $\S 1^{\circ}$, do art. 489 , do CPC/2015 $5^{31}$. Os enunciados do $\S 1^{\circ}$, do art. 489, do CPC/2015 expressam direitos fundamentais do jurisdicionado e uma exigência de cidadania, gerando um controle mais efetivo dos pronunciamentos judiciais, diminuindo a margem de subjetividade quanto à percepção do que é e do que não é uma decisão fundamentada.

A explicitação dos elementos essenciais da sentença no Novo Código de Processo Civil e as hipóteses de taxar como não fundamentada a atuação judicial, decorre de atuação legislativa visando dar maior efetividade ao artigo $5^{\circ}$, inciso LV, da Constituição

em julgamento ou a superação do entendimento" (BRASIL, Código de Processo Civil. Diário Oficial [da] República Federativa do Brasil, Brasília, DF, 16 mar. 2015. Disponível em: < http://www.planalto.gov.br/ccivil_03/_ato2015-2018/2015/lei/113105.htm>. Acesso em: 29 mar. 2019).

29 JACINTHO, Igor. A decisão fundamentada do CPC vs O recente julgado do STJ. 2015. Disponível em < https://ighorf.jusbrasil.com.br/artigos/365177368/a-decisao-fundame ntada-do-cpc-vs-o-recentejulgado-do-stj>. Acesso em: 01 jan. 2019.

30 DIDIER JÚNIOR, Fredie; BRAGA, Paulo Sarno; OLIVEIRA, Rafael Alexandria de. Curso de direito processual civil. v. 2. 10. ed. Salvador: Juspodivm, 2015. p. 326.

31 VASCONCELLOS, Marcos de; ROVER, Tadeu. Juízes pedem veto a artigo que traz regras para fundamentação de decisões. 2015. Disponível em <https://www.conjur.com.br/2015-mar-04/juizes-pedemveto-artigo-cpc-exige-fundamentacao >. Acesso em: 25 jan. 2019. 
Revista Eletrônica de Direito Processual - REDP.

Rio de Janeiro. Ano 13. Volume 20. Número 2. Maio a Agosto de 2019

Periódico Quadrimestral da Pós-Graduação Stricto Sensu em Direito Processual da UERJ

Patrono: José Carlos Barbosa Moreira (in mem.). ISSN 1982-7636. pp. 125-158

www.redp.uerj.br

Federal que assegura aos litigantes, em processo judicial ou administrativo, e aos acusados em geral o contraditório e a ampla defesa, com os meios e recursos a ela inerentes.

É certo que o $\S 1^{\circ}$, do art. 489 , do CPC/2015 torna a confecção das peças processuais mais trabalhosa, sem o que não se pode garantir o direito dos litigantes receberem a mais completa e perfeita tutela jurisdicional ${ }^{32}$. De qualquer modo, é importante compreender cada uma das situações previstas nesse dispositivo.

\subsection{Análise do Inciso I, $\$ 1^{\circ}$, do artigo 489}

O inciso $\mathrm{I}$, do $\S 1^{\circ}$, do art. 489 , do $\mathrm{CPC} / 2015$ considera não fundamentada a deliberação do julgador que se limita à indicação, à reprodução ou à paráfrase de ato normativo, sem explicar sua relação com a causa ou a questão decidida. Assim, é preciso integrar a dimensão normativa, de caráter hipotético, à dimensão fática, cabendo ao julgador demonstrar a aplicabilidade ou não das normas jurídicas à situação concreta posta no processo, fazendo a compatibilização entre as regras e os princípios com o caso concreto e a decisão judicial a ser proferida ${ }^{33}$.

O julgador deve expor, de forma clara e coerente, como obteve a formação do seu convencimento e não apenas proceder com a indicação da norma que aplicou ao caso concreto ou reproduzir o texto de lei. São exemplos de decisões que afrontam esse dispositivo: "Em razão do disposto no art. X, indefiro o pedido"; "Restou caracterizado o abuso do direito de defesa ou o manifesto propósito protelatório da parte, razão pela qual defiro a medida pleiteada" ${ }^{34}$.

\subsection{Interpretação do Inciso II, $\$ 1^{\circ}$, do artigo 489}

O inciso II, do $§ 1^{\circ}$, do artigo 489, do CPC/2015 trata das hipóteses em que o julgador emprega conceitos jurídicos indeterminados sem explicar o motivo concreto de sua

\footnotetext{
32 GOULART, Cristiano. Os elementos essenciais da sentença no novo CPC 2015. A obrigatoriedade da correta fundamentação da sentença. $2015 . \quad$ Disponível em <https://cristianogoulart.jusbrasil.com.br/artigos/209688771/os-elementosessenciais-da-sentenca-no-novocpc-2015>. Acesso em: 01 jan. 2019.

33 Idem. Ibidem.

34 DONIZETTI, Elpídio. Novo Código de Processo Civil comentado. 2a. ed. São Paulo: Atlas, 2017. p. 620 .
} 
incidência no caso. Veda deliberações enquadradas nesses conceitos, sob pena de não serem consideradas fundamentadas.

Consideram-se preceitos jurídicos indeterminados aqueles "cujos termos têm significados intencionalmente vagos e abertos". São os institutos que possibilitam interpretação ampla por parte do julgador, a exemplo da "ordem pública" e do "interesse público"35.

Por força da adoção da técnica legislativa aberta em diversos dispositivos da legislação brasileira, seja pelo emprego de cláusulas gerais, seja pela previsão de conceitos jurídicos indeterminados, não basta o pronunciamento judicial com simples alusão às normas que contenham termos vagos (por exemplo, função social, boa-fé e dignidade da pessoa humana $)^{36}$.

Se bastasse aplicar conceitos indeterminados, isso conduziria à insegurança jurídica. Os conceitos jurídicos indeterminados não são uma espécie de cheque em branco dado ao magistrado para adotar a interpretação que entenda mais adequada à solução da controvérsia. Para evitar abusos, o Código de Processo Civil de 2015 determina que o juiz, ao aplicar esses conceitos, aja com cautela, devendo explicitar, clara e objetivamente, as razões pelas quais adotou essa ou aquela interpretação ${ }^{37}$.

Da mesma forma que é vedado ao juiz utilizar postulados genéricos como a razoabilidade, proporcionalidade e ponderação, sem realizar a justificativa adequada, expondo como as respectivas normas incidem para solucionar os conflitos concretos, também, por analogia, é vedado à parte, por idênticas razões, invocar tais postulados sem realizar a devida justificação de incidência e contribuição interpretativa.

Idêntico raciocínio vale para a aplicação dos princípios nos casos concretos: é preciso demonstrar os estados de coisas que os princípios visam efetivar, a sua finalidade e o modo que estes contribuem para solucionar o caso ${ }^{38}$.

\subsection{Exegese do Inciso III, $\$^{\circ}$, do artigo 489}

\footnotetext{
$35 \quad$ Idem, p. 620-621.

36 MARINONI, Luiz Guilherme. ARENHART. Sérgio Cruz; MITIDIERO, Daniel. Curso de Processo Civil. Tutela dos direitos mediante procedimento comum. 3. ed. vol. 2. Revista dos Tribunais: São Paulo, 2017. p. 100.

37 DONIZETTI, Elpídio. Op. cit., p. 621.

38 MARINONI, Luiz Guilherme. ARENHART. Sérgio Cruz; MITIDIERO, Daniel. Op. cit., p. 100.
} 
O inciso III, do $\S 1^{\circ}$, do artigo 489, do CPC/2015 considera não fundamentada a decisão judicial que invocar motivos que se prestariam a justificar qualquer outra decisão. É fundamental a decisão judicial seja coerente com o quadro fático apresentado pelos envolvidos no processo. A fundamentação do julgado não pode ser contraditória, incompreensível ou gerar dúvida sobre a conclusão adotada pelo magistrado, até porque a atividade jurisdicional, ainda que admita margens de criatividade e inovação, deve respeitar os limites jurídicos e as peculiaridades do caso concreto ${ }^{39}$.

Quer-se, com isso, evitar as chamadas decisões standards, isto é, aquelas desamparadas de relação com o caso concreto. Incentivar tais decisões, ou tolerá-las, seria o mesmo que chancelar a deslegitimação do Poder Judiciário, autorizando a uniformização de argumentos sem o devido enfrentamento com as situações fáticas específicas, o que potencializaria o arbítrio judicial. Assim, a utilização de frases de efeito ou argumentos meramente retóricos, na fundamentação, deve ser evitada, porque não auxilia na resolução das questões de fato e de direito ${ }^{40}$.

O inciso III, do $\S 1^{\circ}$, do artigo 489 , do $\mathrm{CPC} / 2015$ tem grande relevância na atualidade, impedindo a decisão abstrata, na qual o juiz utiliza motivos aptos para qualquer outra situação, até porque há um excessivo número de demandas de massa, decorrente do crescente uso de recursos tecnológicos, com fácil acesso aos bancos de dados de decisões anteriores. O escopo desse dispositivo é impedir que o juiz utilize, indistintamente, decisões-modelo, isto é, decisões baseadas no recorta e cola, sem nenhuma ligação com a situação concreta ${ }^{41}$.

A decisão judicial condiciona-se a um prévio debate entre as partes e o juiz sobre a matéria posta à interpretação e aplicação do direito. A partir do momento que a fundamentação da decisão judicial serve para justificar qualquer outra decisão, sem observar as particularidades da situação concreta, com respostas padronizadas que serviriam indistintamente para a solução de qualquer caso, gerando uma ausência de abordagem das questões fáticas e jurídicas debatidas no processo, caracterizar-se-á a

39 DONIZETTI, Elpídio. Op. cit., p. 621.

40 CAMBI, Eduardo; DOTTI, Rogeria; PINHEIRO, Paulo Eduardo D`arce; KOZIKOSKI, Sandro Marcelo. Curso de processo civil completo. São Paulo: Revista dos Tribunais, 2017. p. 892.

41 RODRIGUES WAMBIER Luiz; TALAMINI Eduardo. Curso avançado de processo civil: cognição jurisdicional, processo comum de conhecimento e tutela provisória. v. 2. 5a. ed. São Paulo: Revista dos Tribunais, 2016. p. 218. 
inexistência de apreciação dos argumentos deduzidos pelas partes.

Quando ocorre uma fundamentação padrão, dissociada da causa, é como se as partes não fossem ouvidas; seu caso não é considerado pelo Judiciário ${ }^{42}$.

\subsection{Exame do Inciso IV, $\$ 1^{\circ}$, do artigo 489 e o entendimento do Superior Tribunal de Justiça}

O artigo 489, $\S 1^{\circ}$, inciso IV, do NCPC decorre das garantias constitucionais da ação (artigo $5^{\circ}$, inciso XXXV) e da ampla defesa (artigo $5^{\circ}$, inciso LV), de modo que tais direitos não sirvam apenas para mover a máquina judicial, mas fazer valer, de modo efetivo, as razões arguidas pelos jurisdicionados em juízo. A postura do julgador deve ser de sujeito do diálogo processual, respondendo as discussões judiciais, em respeito à garantia do contraditório, nos termos do artigo $5^{\circ}$, inciso LV, da Constituição Federal ${ }^{43}$.

O inciso IV, do $\S 1^{\circ}$, do art. 489, do $\mathrm{CPC} / 2015$, não aceita como fundamentada a deliberação judicial quando esta "não enfrentar todos os argumentos deduzidos no processo capazes de, em tese, infirmar a conclusão adotada pelo julgador". Trata-se da hipótese de vício de fundamentação, deixando clara a intrínseca ligação existente entre o dever de fundamentação das decisões e a garantia constitucional do contraditório, assegurando a participação dos envolvidos de forma ampla no processo. O contraditório não é só o direito de falar, englobando também o direito de ser ouvido; não há contraditório efetivo se as argumentações deduzidas pelos litigantes não são levadas em consideração na decisão judicial ${ }^{44}$.

A análise dos argumentos das partes, seja por manifestação própria, seja por indicação do juiz (Hinweispflicht), cria uma expectativa legítima para os litigantes de que a decisão judicial será restrita à moldura inserida no debate processual. Com isso, legitima-se o direito à segurança jurídica no processo, com a vedação de decisões surpresas (Verbot der Überraschungsentscheidungen), decorrendo daí a necessidade de diálogo efetivo entre parte e juiz. O caráter lógico-argumentativo da interpretação do direito repele a decisão

42 MARINONI, Luiz Guilherme; ARENHART. Sérgio Cruz; MITIDIERO, Daniel. Op. cit., p. 327.

43 CAMBI, Eduardo; DOTTI, Rogeria; PINHEIRO, Paulo Eduardo D`arce; KOZIKOSKI, Sandro Marcelo. Op. cit., p. 895.

44 CÂMARA, Alexandre Freitas. O novo processo civil brasileiro. 3a. ed. São Paulo: Atlas, 2017. p. 26. 
judicial que não confronta todos os argumentos deduzidos no processo, capazes, em tese, de modificar a decisão do julgador ${ }^{45}$.

A decisão judicial deve examinar todos os fundamentos do processo e não só aqueles que convergem para a decisão. Porém, antes da vigência do CPC de 2015, entendia-se que o contraditório estaria respeitado, na seara da fundamentação das decisões judiciais, ainda que a deliberação judicial não tivesse correlação com a atividade desenvolvida pelas partes em juízo; ou seja, o órgão jurisdicional teria considerada como motivada a sua decisão ainda que esta tivesse suas razões em argumentos não invocados ou oportunizados para apreciação às partes. Exigia-se apenas a não contradição dos argumentos constantes na decisão, pois partia-se de um critério intrínseco para constatar a plenitude de motivação ${ }^{46}$.

No entanto, esse entendimento não mais se justifica diante da nova visão da garantia constitucional do contraditório enfatizada pelo Código de Processo Civil de 2015. Contraditório significa o direito de influir diretamente na decisão judicial, conforme exposto nos artigos $7^{\circ}, 9^{\circ}$ e $10^{\circ}$ do $\mathrm{CPC} / 2015$. Para tanto, deve-se respeitar o direito ao amplo diálogo e debate judiciais. Assim, esvazia-se o contraditório quando não se rebatem os fundamentos invocados pelas partes. Portanto, exige-se, além da não contradição da decisão, que a fundamentação seja pautada na criteriosa consideração dos argumentos tecidos pelas partes ao longo do processo ${ }^{47}$.

Na vigência do Novo CPC, os órgãos julgadores estão adstritos ao enfrentamento de todos os argumentos deduzidos pelas partes no processo, capazes de infirmar sua convicção. Nesse sentido, pelo enunciado 40 da Escola Nacional de Formação e Aperfeiçoamento de Magistrados (ENFAM), compete ao recorrente demonstrar que o argumento omitido é capaz de mudar o entendimento do julgador ${ }^{48}$. Dessa forma, promovem um desserviço contra a pacificação social as decisões judiciais que ignoram argumentos relevantes aventados pelas partes, deixando os litigantes à mercê dos motivos do julgamento, ao passo que retiram deles a possibilidade de serem convencidos do acerto da decisão ${ }^{49}$.

\footnotetext{
45 MARINONI, Luiz Guilherme. ARENHART. Sérgio Cruz; MITIDIERO, Daniel. Op. cit., p. 327.

$46 \quad$ Idem, p. 328.

47 Idem. Ibidem.

48 KOZIKOSKI, Sandro Marcelo. Sistema Recursal - CPC 2015: em conformidade com a Lei 13.256/2016. Salvador: Juspodivm, 2016. p. 194.

49 CAMBI, Eduardo; DOTTI, Rogeria; PINHEIRO, Paulo Eduardo D`arce; KOZIKOSKI, Sandro Marcelo. Op. cit., p. 899.
} 
O CPC/2015 está calcado no dever de diálogo entre partes e juízes como mecanismo efetivador do contraditório, ao garantir plena participação nos atos, sessões, fases do processo, tudo para influenciar a convicção do julgador. Contudo, de nada adianta assegurar a plenitude do contraditório e autorizar o julgador a não enfrentar todas alegações relevantes deduzidas no processo ${ }^{50}$.

O inciso IV, do $\S^{\circ}$, do art. 489, do CPC/2015 não impõe aos juízes de primeiro grau, os desembargadores das Cortes de Justiça (Tribunais de Justiça e Tribunais Regionais Federais), os Ministros das Cortes Supremas (Supremo Tribunal Federal e Superior Tribunal de Justiça), o dever de rebater todos os argumentos deduzidos pelas partes. O dever de fundamentação se restringe aos motivos relevantes, isto é, aos argumentos principais arguidos no processo, capazes de, por si só, levar a procedência ou improcedência de um pedido ou ao conhecimento, provimento ou improvimento de um recurso $^{51}$.

Logo, com a vigência do CPC/2015, o Judiciário deve apreciar todas as teses principais do processo, relevantes o suficiente para influir no resultado do julgamento. $\mathrm{O}$ órgão jurisdicional deve levar em consideração todos os argumentos suscitados pelas partes, capazes, em tese, de levar a uma decisão favorável ${ }^{52}$.

Destaca-se que o ordenamento jurídico não admite a escolha aleatória de um fato diverso para embasar a ato de decidir, desprezando o contraditório e a ampla defesa. A decisão deve se explicar, mostrar de onde veio, sob pena de gerar descrença à atividade jurisdicional, visto que a deliberação deve ser construída no decorrer do processo, ponderando as alegações das partes, as provas e circunstâncias de cada caso concreto. Toda a argumentação relevante deduzida no processo deve ser levada em consideração quando da elaboração da decisão, especialmente em se tratando de sentença ou acórdão ${ }^{53}$.

Por outro lado, não se pode aceitar, com o advento do Novo Código de Processo Civil, julgamentos como os proferidos no passado; a título ilustrativo, deve-se rechaçar o posicionamento contido no Agravo Regimental julgado no Recurso Especial no 373.611 (2001/0157956-3), na qual entendia pela dispensabilidade dos argumentos das partes,

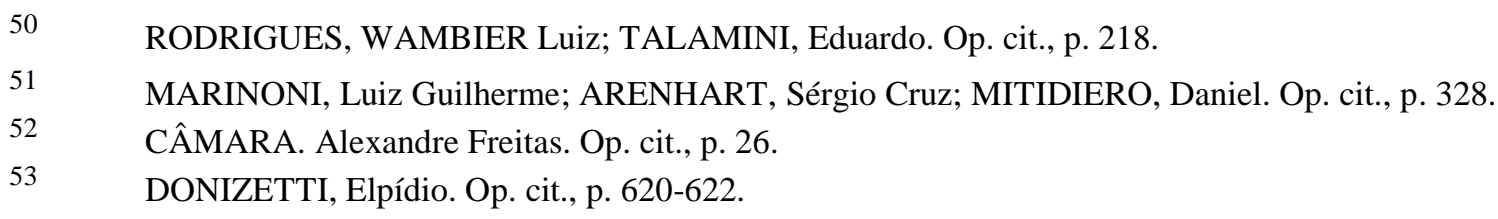


Revista Eletrônica de Direito Processual - REDP.

Rio de Janeiro. Ano 13. Volume 20. Número 2. Maio a Agosto de 2019

Periódico Quadrimestral da Pós-Graduação Stricto Sensu em Direito Processual da UERJ

Patrono: José Carlos Barbosa Moreira (in mem.). ISSN 1982-7636. pp. 125-158

www.redp.uerj.br

deixando o julgador livre para julgar da forma que bem entendesse adequada, desde que com base nas provas, fatos ou jurisprudência e demais estudos do tema ${ }^{54}$.

Não existe mais a expressão "livre convencimento" no NCPC e isso se deve à preocupação em banir decisões judiciais baseadas em pressupostos internos/subjetivos. $\mathrm{O}$ livre convencimento é, pois, irmão gêmeo do particularismo subjetivista, que deve ser refutado $^{55}$. Não será o juiz que fará impor sua visão particular de mundo, para corrigir moralmente as leis tidas por ele como defeituosas, mas deve levar a sério o seu compromisso de fazer valer a Constituição e a legislação democraticamente constituída ${ }^{56}$.

Ademais, o princípio do livre convencimento motivado do juiz deve ser aperfeiçoado pelo princípio da completude da motivação, na qual o órgão judicial deve, racionalmente, justificar o seu convencimento, seja no momento de interpretação das regras/princípios, seja no momento de valoração da prova.

O artigo 489, $\S 1^{\circ}$, inciso IV, do NCPC adota o princípio da completude da motivação mitigado, ao não considerar fundamentada a decisão judicial que não enfrenta todos os argumentos deduzidos no processo capazes de, em tese, modificar a conclusão utilizada pelo julgador ${ }^{57}$. Assim, não se pode mais admitir que seja franqueado aos julgadores, omitir, em escala, o que quiser ignorar, cabendo demonstrar, de modo explícito que as questões ignoradas não se mostram relevantes ${ }^{58}$.

Entretanto, há diversos precedentes do Superior Tribunal de Justiça no sentido de

54 "2. Inocorrência de irregularidades no acórdão quando a matéria que serviu de base a interposição do recurso foi devidamente apreciada no aresto atacado, com fundamentos claros e nítidos, enfrentando as questões suscitadas ao longo da instrução, tudo em perfeita consonância com os ditames da legislação e jurisprudência consolidada. O não acatamento das argumentações deduzidas no recurso não implica em cerceamento de defesa, posto que ao julgador cumpre apreciar o tema de acordo com o que reputar atinente à lide. 3. Não está obrigado o Magistrado a julgar a questão posta a seu exame de acordo com o pleiteado pelas partes, mas, sim, com o seu livre convencimento (art. 131, do CPC), utilizando-se dos fatos, provas, jurisprudência, aspectos pertinentes ao tema e da legislação que entender aplicável ao caso concreto" (BRASIL, Superior Tribunal de Justiça. Agravo regimental no especial no 373.611 - RJ/2001/157956-3. Partes litigantes Companhia Siderúrgica Belgo-minelra e Fazenda Nacional. Primeira turma. Ministro José Delgado. Julgado em 26 fev. 2002.Diário da Justiça Eletrônico [da] República Federativa do Brasil, 25 mar. 2003. Disponível

em: $<$ https://ww2.stj.jus.br/processo/revista/documento/mediado/?componente=IMGD\&sequencial=90270\&num _registro $=200101579563 \&$ data $=20020325 \&$ formato=PDF>. Acesso em: 28 jan. 2019).

55 STRECK. Lenio Luiz. O que é isto - decido conforme minha consciência? 6. ed. Porto Alegre: Livraria do Advogado, 2017. p. 37-38.

56 Idem, p. 123.

57 CAMBI, Eduardo. Op. cit., p. 434.

58 MARCACINI. Augusto Tavares Rosa. Op. cit., p. 93. 
Revista Eletrônica de Direito Processual - REDP.

Rio de Janeiro. Ano 13. Volume 20. Número 2. Maio a Agosto de 2019

Periódico Quadrimestral da Pós-Graduação Stricto Sensu em Direito Processual da UERJ

Patrono: José Carlos Barbosa Moreira (in mem.). ISSN 1982-7636. pp. 125-158

www.redp.uerj.br

dispor que o julgador não está obrigado a responder todas as questões arguidas pelas partes, quando encontra motivo suficiente para proferir decisão, chegando ao extremo de afirmar que o artigo 489, § $1^{\circ}$, do Novo Código de Processo Civil de 2015 confirma a jurisprudência consolidada da corte superior na vigência do Código de Processo Civil de $1973^{59}$.

Nesse ínterim, na contramão da previsão expressa do artigo 489, § $1^{\circ}$, do Novo Código de Processo Civil, verifica-se forte resistência do Superior Tribunal de Justiça, seguida pelos tribunais inferiores da federação, de conferir interpretação destoante do pretendido pelo legislador, principalmente no que tange ao artigo 489, parágrafo primeiro, inciso IV, conforme se nota, a título exemplificativo, nos Embargos de Declaração no Mandado de Segurança n ${ }^{\mathrm{o}} 21.315 / \mathrm{DF}^{60}$ e no Recursos Especiais n ${ }^{\mathrm{o}} 1676573 / \mathrm{PE}^{61}$.

No mesmo sentido, o STJ, no Agravo Interno no Recurso Especial no 1.310 .033 $\mathrm{SP}^{62}$, asseverou que o julgador não é obrigado a rebater todos os argumentos da parte de 59 NEVES, Daniel Amorim Assumpção. Novo CPC para advogados. V.2. São Paulo: Método, 2018. p. 82.

$60 \quad$ "O julgador não está obrigado a responder a todas as questões suscitadas pelas partes, quando já tenha encontrado motivo suficiente para proferir a decisão. A prescrição trazida pelo art. 489 do CPC/2015 veio confirmar a jurisprudência já sedimentada pelo Colendo Superior Tribunal de Justiça, sendo dever do julgador apenas enfrentar as questões capazes de infirmar a conclusão adotada na decisão recorrida. (BRASIL, Superior Tribunal de Justiça. Diário [da] Justiça Eletrônico Embargos de Declaração no Mandado de Segurança $n^{\circ}$ 21.315/DF. Embargante: Paulo Rodrigues Vieira. Embargado: União Federal. Relatora: Ministra Diva Malerbi. Disponível em: $<$ https://ww2.stj.jus.br/processo/revista/documento/mediado/?componente=ATC\&sequencial=61426619\&nu m_registro $=201402570569 \&$ data $=20160615 \&$ tipo $=51 \&$ formato=PDF $>$. Acesso em: 22 ago. 2018).

61 “3. 'O julgador não está obrigado a responder a todas as questões suscitadas pelas partes, quando já tenha encontrado motivo suficiente para proferir a decisão. A prescrição trazida pelo art. 489 do CPC/2015 veio confirmar a jurisprudência já sedimentada pelo Colendo Superior Tribunal de Justiça, sendo dever do julgador apenas enfrentar as questões capazes de infirmar a conclusão adotada na decisão recorrida' (EDcl no AgRg nos EREsp 1.483.155/BA, Rel. Ministro Og Fernandes, Corte Especial, DJe de 3.8.2016). 4. Na hipótese dos autos, a questão de mérito foi detidamente analisada e entregue a prestação jurisdicional de forma adequada, não se constatando a fundamentação genérica capaz de gerar a nulidade pretendida pelo recorrente.5. Recurso Especial não provido" (BRASIL, Superior Tribunal de Justiça. Recurso especial $n^{\circ}$ 1.676.573 - PE (2017/0133468-0). Partes litigantes Ministério Público do Estado de Pernambuco e Fernando Antônio de Sá de Oliveira Filho. Relator Ministro Herman Benjamin. Segunda turma. Julgado em 21. nov. 2017.Diário da Justiça Eletrônico [da] República Federativa do Brasil, 21 nov. 2017. Disponível em: <https://ww2.stj.jus.br/processo/revista/documento/mediado/?componente=ITA\&sequencial=1636614\&num _registro=201701334680\&data=20171219\&formato=PDF>. Acesso em: 29 set. 2018).

62 Superior Tribunal de Justiça. Agravo interno no agravo no recurso especial $\mathrm{n}^{\circ} 1.310 .033-\mathrm{SP}$ (2018/0144380-6). Partes litigantes Polimold Industrial S/A e Fazenda Nacional. Relator Ministro Francisco Falcão. Segunda turma. Julgado em 13. nov. 2018. .Diário da Justiça Eletrônico [da] República Federativa do Brasil, 
forma individualizada, devendo apenas enfrentar a demanda e observar as questões relevantes e imprescindíveis para a resolução. No entanto, ao revés do apontado, a inexistência de abordagens dos pontos invocados pelas partes, capazes de alterar o entendimento do julgador, devem ser apreciados, sob pena da decisão ser considerada não fundamentada.

Essa corrente, equivocada, sustentando que o juiz não precisa se manifestar a respeito de todos as alegações das partes foi facilitada pela falta de disposição expressa no antigo Código de Processo Civil de 1973 e enraizou-se no Poder Judiciário que passou a sustentar que basta a apresentação das razões de seu convencimento. Em outras palavras, com fundamento no CPC/73, entendia-se admissível a mera escolha dos argumentos benéficos para a parte vencedora, pouco importando as alegações da parte vencida ${ }^{63}$.

Ou seja, de acordo com a jurisprudência sedimentada do Superior Tribunal de Justiça (a título exemplificativo, vide julgados descritos no decorrer deste tópico), ainda que esteja expressamente escrito no dispositivo legal que o magistrado deverá enfrentar todos os argumentos deduzidos no processo, à luz do entendimento do STJ, o julgador não está obrigado a responder a todas as questões suscitadas pelas partes ${ }^{64}$.

Essa orientação jurisprudencial é praticamente majoritária ou unívoca no STJ, que demonstra ser necessária apenas a resolução da controvérsia judicial, sem necessidade de rebater os argumentos trazidos pelas partes. Entretanto, essa exegese nega vigência ao inciso IV, do §1. ${ }^{\circ}$, do artigo 489, do CPC/2015, pois não se deve considerar fundamentada qualquer decisão judicial que não enfrentar todos os argumentos deduzidos no processo capazes de, em tese, infirmar a conclusão adotada pelo julgador.

Todavia, ao revés do apontado pelo Superior Tribunal de Justiça, a possibilidade do julgador discutir amplamente os argumentos das partes não pode ser situação impossível, desde que sejam utilizadas técnicas processuais adequadas. Isso deve ocorrer até para que o órgão jurisdicional tenha mais subsídios claros e precisos para pronunciar-se sobre todos os argumentos discutidos no processo, visando fomentar o diálogo aliado ao contraditório

em: $<$ https://ww2.stj.jus.br/processo/revista/documento/mediado/?componente $=I T A \&$ sequencial $=1770078 \& \mathrm{n}$ um_registro $=201801443806 \&$ data $=20181121 \&$ formato $=P D F>$.Acesso em: 29 set. 2018.

63 LUCCA, Rodrigo Ramina de. O dever de motivação das decisões judiciais: Estado de direito, segurança jurídica e teoria dos precedentes. 2a. ed. Salvador: Juspodivm, 2016.

64 JACINTHO, Igor. Op. cit. 
efetivo $^{65}$. Por exemplo, na Alemanha, tal dever, denominado de Anspruch auf rechtliches gehor e que decorre da garantia do contraditório, assegura às partes o direito de verem seus argumentos considerados ${ }^{66}$.

Portanto, não se pode concordar com o entendimento do STJ, uma vez que se trata de clara jurisprudência defensiva, com evidente viés de amenizar a sobrecarga de trabalho dos tribunais, para evitar do julgador analisar todos os pontos invocados pelos envolvidos no processo. Porém, há outras formas mais racionais de uniformização das decisões judiciais e contenção de demandas judiciais repetitivas previstas no Novo Código de Processo Civil (como a utilização dos precedentes, o uso do incidente de demandas repetitivas e de assunção de competência, etc). Ao contrário, a orientação do STJ não contribui para a melhoria da prestação jurisdicional, ao sacrificar as garantias fundamentais do contraditório e da ampla defesa, negando vigência ao artigo $5^{\circ}$, inciso LV, da Constituição Federal, com o efeito de deixar as partes à mercê da sorte do aplicador do direito analisar, ou não, os seus argumentos, ainda que se trate de tese principal, capaz de modificar a convicção judicial.

\subsection{Análise do Inciso $\mathrm{V}, \mathbf{\$} 1^{\circ}$, do artigo 489}

$\mathrm{O}$ inciso $\mathrm{V}$, do $\S 1^{\circ}$, do art. 489, do $\mathrm{CPC} / 2015$ rechaça a decisão judicial que "se limitar a invocar precedente ou enunciado de súmula, sem identificar seus fundamentos determinantes nem demonstrar que o caso sob julgamento se ajusta àqueles fundamentos". Não corresponde a fundamentação válida a decisão judicial que simplesmente invoca um precedente sem demonstrar a sua pertinência com o caso concreto. Significa ser insuficiente o julgador citá-lo e torna-se imprescindível a análise da correspondência da sua tese com o caso debatido em juízo ${ }^{67}$. Assim, o dever de fundamentação das decisões é considerado afrontado em casos nos quais o órgão jurisdicional se limita a expor ementas de outros acórdãos em que teriam sido decididos casos iguais ou análogos ${ }^{68}$.

65 CERQUEIRA, Vinícius Nascimento. Fundamentos da decisão no novo CPC: O contraditório forte e os precedentes. Jundiaí: Paco Editorial: 2014. p. 191.

66 STRECK. Lenio Luiz. Op. cit, p. 48.

67 FLUMIGNAN, Silvano José Gomes. Novo CPC exige conceito técnico do que significa precedente. 2015. Disponível em <https://www.conjur.com.br/2015-jul-11/cpc-exige-conceito-tecnico-significaprecedente>. Acesso em: 22 jan. 2019.

68 CÂMARA, Alexandre Freitas. Op. cit., p. 27. 
Nota-se que o inciso V se trata de hipótese similar ao inciso I, do $\S 1^{\circ}$, do mesmo Código, só que há um fator adicional: a tendência de seguir de forma indiscriminada precedentes e enunciados de súmulas, sem verificar quanto ao encaixe dos seus pressupostos no caso submetido a julgamento, torna a decisão nula ${ }^{69}$. Tal dispositivo procura combater a prática das pseudofundamentações, isto é, aquelas decisões que, a pretexto de analisarem as razões de origem e aplicação dos precedentes, limitam-se apenas a mencionar emendas de enunciados ou julgados de súmulas, sem realizar a correlação necessária e adequada entre o caso paradigma e o caso concreto $^{70}$.

A mera indicação de ementas não é a forma correta para a invocação dos precedentes. Para adotar um precedente ou enunciado de súmula, deve-se examinar os fundamentos determinantes (ratio decidendi) da decisão alegada como precedente, demonstrando-se claramente que o caso anterior se amolda ao que está sendo decidido, não se prescindindo da identidade com o precedente e da justificação de sua aplicação ${ }^{71}$.

Impõe-se, nos termos do artigo 489, § 1. ${ }^{\circ}$, VI, a necessidade da decisão judicial possuir uma fundamentação analítica. O magistrado deve identificar, de forma precisa, os fundamentos determinantes que conduziram a formação da tese jurídica e, em seguida, argumentar se são os mais apropriados para a resolução do caso concreto $^{72}$. A concatenação lógica e fática é, pois, um pressuposto para a garantia do direito ao esclarecimento do conteúdo decisório" 73 .

\subsection{Interpretação do Inciso VI, $\S^{\circ}$, do artigo 489}

O inciso VI, do $§ 1^{\circ}$, do artigo 489, do CPC/2015 torna inadmissível "deixar de seguir enunciado de súmula, jurisprudência ou precedente invocado pela parte, sem demonstrar a existência de distinção no caso em julgamento ou a superação do entendimento" ${ }^{\text {", }}$,

\footnotetext{
69 MEDINA, José Miguel Garcia. Curso de direito processual civil moderno. 3a. ed. São Paulo: Revista dos Tribunais, 2017. p. 712.

70 CAMBI, Eduardo; DOTTI, Rogeria; PINHEIRO, Paulo Eduardo D`arce; KOZIKOSKI, Sandro Marcelo. Op. cit. p. 900.

71 CÂMARA, Alexandre Freitas. Op. cit., p. 27.

72 WAMBIER, Luiz Rodrigues; TALAMINI Eduardo. Op. cit., p. 218.

73 ARAÚJO, Fábio Caldas de. Op. cit., p. 159.

74 BRASIL, Código de Processo Civil. Diário Oficial [da] República Federativa do Brasil, Brasília, DF, 16 mar. 2015. Disponível em: <http://www.planalto.gov.br/ccivil_03/_ato20152018/2015/lei/l13105.htm>. Acesso em: 12 mar. 2019.
} 
penalizando o ato judicial enquadrado neste dispositivo, de não fundamentado. Trata-se de hipótese que exige justificação para afastar a sua ocorrência no caso concreto.

É de se aceitar que o $\$ 1^{\circ}$ do artigo 489 do CPC faz imperar a obrigação de fundamentação substancial da decisão judicial, com alusão aos motivos determinantes do precedente ou súmula invocados (inciso V), ou alusão à distinção adequada (inciso VI), para fins de deixar de seguir jurisprudência, enunciado de súmula ou precedente invocado pela parte ${ }^{75}$.

Decisão judicial que deixa de seguir enunciado de súmula, jurisprudência ou precedente invocado pela parte, sem demonstrar a existência de distinção no caso em julgamento ou a superação do entendimento, incorre em vício de fundamentação. A decisão judicial não se legitima constitucionalmente quando a parte tenha aventado precedente ou enunciado de súmula ou jurisprudência dominante que lhe seja favoreça e o juízo nega-se a indicar os motivos para afastar a sua incidência no caso concreto. Nessas situações, é dever do julgador apontar a distinção (distinguishing) entre o precedente e o caso objeto de debate, ou lhe incumbe demonstrar motivadamente a superação do entendimento adotado no precedente, o que se denomina de overruling ${ }^{76}$.

A aplicação da ratio decidendi de um precedente em um caso concreto depende da verificação das semelhanças entre os casos, por meio da analogia. Por outro lado, o distinguishing é a atividade inversa, em que se buscam as diferenças entre os casos para afastar a aplicação indesejável da ratio de um presente envolvendo situação substancialmente diferente da que está sendo julgada ${ }^{77}$.

De igual forma, quando se deixa de aplicar enunciado de súmula, precedente ou jurisprudência, o julgador deve realizar o confronto analítico, deixando claro os motivos do caso sob julgamento para distinguir-se do caso paradigma ou demonstrar a superação desse entendimento $^{78}$. Logo, deixar-se guiar por orientação pacificada na jurisprudência, sem demonstrar as diferenças (distinguishing), ou sem evienciar que o caso apontado está com orientação superada (overruling), caracteriza afronta ao dever de fundamentação ${ }^{79}$.

\footnotetext{
75 KOZIKOSKI, Sandro Marcelo. Op. cit., p. 193.

76 CÂMARA, Alexandre Freitas. Op. cit., p. 27.

77 KREBS. Hélio Ricardo Diniz. Sistema de precedentes e direitos fundamentais. São Paulo: Revista dos Tribunais, 2015. p. 211-212.

78 WAMBIER, Luiz Rodrigues; TALAMINI, Eduardo. Op. cit., p. 218.

79 MEDINA, José Miguel Garcia. Op. cit., p. 712-713.
} 
O inciso VI, do $§ 1^{\circ}$, do artigo 489, do CPC/2015, ao mesmo tempo que demonstra a força dos precedentes posta no artigo 927 do CPC/2015, é uma ferramenta fundamental para provocar mudanças e instigar a permanente sintonia entre a jurisprudência e a realidade. O juiz, rejeitando a aplicação da jurisprudência, súmula ou da orientação já existente, oxigenará e enriquecerá o sistema jurídico, mas para tanto precisa assumir o ônus argumentativo e demonstrar a superação da tese ou a sua inaplicabilidade para o novo caso analisado (overruling). Nessas situações, cabe ao órgão julgador salientar a especificidade do caso em julgamento e expor a impossibilidade de subsunção ao que já foi decidido $^{80}$.

Não se pode esquecer, contudo, que a parte também de o ônus de invocar o enunciado de súmula, jurisprudência ou precedente, bem como argumentar se a determinada ratio decidendi é compatível com o caso concreto em julgamento. Quando a parte realiza a citação sistemática de jurisprudências, súmulas ou precedentes, sem argumentação específica, expondo as razões essenciais para que a orientação seja seguida, fere os princípios da boa-fé objetiva (art. $5^{\circ}$ do NCPC) e da cooperação processual (art. $6^{\circ}$ do NCPC), podendo prejudicar a tutela dos seus interesses, tendo em vista que a sua omissão pode dificultar a solução integral do mérito em prazo razoável (art. $4^{\circ}$, do $\mathrm{NCPC})^{81}$.

Ademais, a referência genérica a julgados, sem que seus fundamentos determinantes sejam identificados e sem que se demonstre que tais fundamentos aplicam-se ao caso podem conduzir a que se considere inepta a petição inicial (art. 330, §1. ${ }^{\circ}$, III, do CPC/2015). Além disso, se a parte não conseguir se desincumbir de demonstrar a incidência (ou não) do precedente, poderá ter seu pedido liminarmente rejeitado (artigo 332, caput e incisos do CPC/2015) ou ser negada a tutela de evidência requerida, nos termos do artigo 311 , inciso II, do $\mathrm{CPC} / 2015^{82}$.

Todavia, desincumbindo-se a parte deste ônus da argumentação, será dever do julgador realizar análise pormenorizada dos casos, fazendo a comparação de suas características. Optando por não seguir as razões jurídicas invocadas no enunciado de súmula, jurisprudência ou precedente, terá o dever de justificar os motivos de divergência

80 ARAÚJO, Fábio Caldas de. Op. cit., p. 159-160.

81 CAMBI, Eduardo; DOTTI, Rogeria; PINHEIRO, Paulo Eduardo D`arce; KOZIKOSKI, Sandro Marcelo, Op. cit., p. 904.

82 MEDINA, José Miguel Garcia. Op. cit., p. 713. 
ou de superação do entendimento invocado ${ }^{83}$.

\section{Decisões judiciais embargáveis: a relação do artigo 489 , $§ 1^{\circ}$, com os artigos}

\subsection{2 do CPC/2015 e 93, inciso IX, da CF/88}

No passado, admitia-se embargos de declaração apenas contra sentença ou acórdão. Com o avançar dos anos passou-se a conhecer desse recurso em face de decisões interlocutórias e, com a novel legislação processual civil, o artigo 1.022, caput, aceita a interposição de embargos de declaração contra qualquer decisão judicial, independentemente do procedimento adotado ${ }^{84}$.

$\mathrm{O}$ artigo 489, $\S 1^{\circ}$, do $\mathrm{CPC} / 2015$ concretiza garantias processuais previstas na Constituição Federal, com aplicabilidade a todo o sistema judiciário brasileiro. Não se trata de mera averiguação e não deve ser aplicado em uma perspectiva meramente formalista ${ }^{85}$. Assim, exige-se do magistrado, em qualquer decisão judicial, o dever de fundamentar todas as questões suscitadas pelas partes. Ainda que de forma sucinta, a fundamentação não pode ser inadequada ou genérica, sob pena de violação dos artigos 93, inciso IX, da $\mathrm{CF}$, e 11 do $\mathrm{CPC} / 2015^{86}$.

O Novo CPC exige dos julgadores uma atuação jurisdicional intensa e específica, voltada para a solução do caso concreto. Nesse sentido, o Tribunal de Justiça do Estado do Paraná considerou, na apelação cível n ${ }^{\circ}$ 638649-0, oriunda da $16^{a}$ Câmara Cível, sem fundamentação a decisão judicial que, valendo-se de motivação genérica, não se atentou para as particularidades do feito posto ao Juízo ${ }^{87}$.

Assim, a decisão judicial sem fundamentação ou com pseudomotivação (violação ao art. $489, \S 1^{\circ}$, no Novo CPC) é absolutamente nula. Por isso, o juiz que se limita a copiar texto legal para fundamentar a decisão judicial sem explicar sua correlação com o caso

83 CAMBI, Eduardo; DOTTI, Rogeria; PINHEIRO, Paulo Eduardo D`arce; KOZIKOSKI, Sandro Marcelo, Op. cit., p. 905.

84 DIDIER JÚNIOR, Fredie; CARNEIRO DA CUNHA, Leonardo. Curso de direito processual civil. v. 3. 13a. ed. Salvador: Juspodivm, 2016. p. 258.

85 STRECK, Lenio Luiz. Op. cit., p. 25.

86 PAULA, Jônatas Luiz Moreira de. Curso de processo civil: processo de conhecimento no novo CPC. 2a. ed. Belo Horizonte: D’Plácido, 2016. p. 418.

87 Idem, p. 419. 
Revista Eletrônica de Direito Processual - REDP.

Rio de Janeiro. Ano 13. Volume 20. Número 2. Maio a Agosto de 2019

Periódico Quadrimestral da Pós-Graduação Stricto Sensu em Direito Processual da UERJ

Patrono: José Carlos Barbosa Moreira (in mem.). ISSN 1982-7636. pp. 125-158

www.redp.uerj.br

concreto afronta a exigência da fundamentação válida ${ }^{88}$. A interpretação e aplicação dos textos normativos exige a tomada de posição por parte da autoridade institucionalmente reconhecida, sendo inadmitida a ausência de definição, calcada em mera repetição da norma, sem explicação da ligação com a facticidade da causa ${ }^{89}$.

Nessa situação, a parte prejudicada pode interpor embargos de declaração, sem o risco destes serem considerados protelatórios, pois o artigo 1022, parágrafo único, inciso II, do CPC/2015 dispõe se tratar de hipótese de omissão ${ }^{90 .}$ É certo que as decisões com vício de fundamentação são inconstitucionais, podendo tal vício ser suprido por meio de embargos declaratórios interpostos no prazo legal ${ }^{91}$.

Ainda, a carência de fundamentação, de acordo com o critério do $\S 1^{\circ}$ do artigo 489 do Código de Processo Civil, poderá ensejar a interposição de embargos declaratórios, no prazo de 5 (cinco) dias (artigo 1.022, parágrafo único), para esclarecimento da fundamentação ou a interposição de recurso de apelação ou especial/extraordinário, no prazo de 15 (quinze) dias, com a finalidade de anulação da decisão ${ }^{92}$.

Nesse tópico, o foco da análise será o inciso II, do parágrafo único do art. 1.022 do CPC/2015 que considera omissa a decisão que incorrer em qualquer das condutas inseridas no $\S 1^{\circ}$ do artigo 489 do CPC/2015. Nessas situações, os embargos de declaração atuarão como uma técnica corretiva da fundamentação da decisão ${ }^{93}$.

Logo, caso a decisão judicial não seja fundamentada de forma adequada, poderá a parte valer-se dos embargos de declaração, que é um recurso cabível tanto para o processo

88 NEVES, Daniel Amorim Assumpção Op. cit., p. 80.

89 GIORGI JÚNIOR, Romulo Ponticelli. Jurisdição Constitucional e o Código de Processo Civil: sincronia, racionalidade, interpretação e segurança jurídica. São Paulo: Revista dos Tribunais, 2017. p. 168. 90 BRASIL, Código de Processo Civil. Diário Oficial [da] República Federativa do Brasil, Brasília, DF, 16 mar. 2015. Disponível em: <http://www.planalto.gov.br/ccivil_03/_ato20152018/2015/lei/113105.htm>. Acesso em: 12 mar. 2019.

91 "É certo que as decisões com vício de fundamentação são inconstitucionais (CF/88, art. 93, IX; CPC, art. 11). Mas, a tradição brasileira consagrou a possibilidade de correção de decisões obscuras ou contraditórias, corrigindo ainda certas omissões com a integração dos pontos e questões relevantes da causa. Assim, o art. 1022 do CPC assentou que os embargos de declaração são cabíveis em face de qualquer decisão judicial, independente do grau de jurisdição. Ainda que o legislador venha a dispor que uma decisão é irrecorrível, ao serem identificados os vícios elencados no art. 1022 do CPC, os embargos declaratórios devem ser aceitos por forca do princípio da ampla embargabilidade" (KOZIKOSKI, Sandro Marcelo. Op. cit., p. 193-194).

92 PAULA, Jônatas Luiz Moreira de. Op. cit., p. 420.

93 SCHMITZ, Leonard Ziesemer. Fundamentação das decisões judiciais: a crise na construção de respostas no processo civil. São Paulo: Revista dos Tribunais, 2015. p. 296. 
civil, como para o processo penal e do trabalho, que tem como um dos seus primados suprir omissões em decisões judiciais. Ademais, oportuno destacar que a interposição de embargos declaratórios chega a ser até mesmo um requisito exigido pelo STJ/STF, para conhecer e julgar recurso especial/extraordinário, quando instância judicial inferior se omite em aplicar lei ou ato normativo contrário à Constituição Federal ${ }^{94}$.

Extrai-se do artigo 1.022, e seus incisos, do CPC/2015 que os embargos de declaração são cabíveis quando constar, na decisão recorrida, obscuridade, contradição ou omissão em ponto sobre o qual deveria ter se pronunciado o julgador, ou quando pelas condutas descritas no artigo 489, parágrafo $1^{\circ}$, restar configurada hipótese de carência de fundamentação válida.

Todavia, a jurisprudência, como regra geral, só admite embargos de declaração em omissões decorrentes da análise de requerimentos ou pedidos formulados pelas partes, quando envolvem a parte dispositiva. Nem para fins de prequestionamento os tribunais brasileiros costumam admitir o provimento dos embargos declaratórios, para sanar omissões de seus acórdãos, à exceção de recursos especiais/extraordinários em face destas decisões. Assim, a prática revela difícil provimento de recursos contra omissões de motivação, sejam eles objeto de embargos de declaração, apelação, agravos, entre outros. Tal postura judicial decorre da má compreensão do dever funcional de motivação das decisões judiciais e do significado das relevantes questões do processo. Necessita-se romper a crença jurisprudencial generalizada de que cabe ao juiz escolher as alegações das partes dignas de apreço, desprezando o supostamente considerado impertinente ${ }^{95}$.

É insuficiente a resposta judicial quando o juiz deixa de examinar todas as alegações trazidas pelas partes, elegendo algumas e afastando outras ${ }^{96}$. Afinal, as decisões insuficientemente motivadas ocultam uma parcela de poder arbitrário ${ }^{97}$.

$\mathrm{Na}$ prática, pouco ou nada tem importado a existência dos vícios tratados no artigo 1.022 do NCPC, eis que, por meio de decisões absolutamente carentes de fundamentos,

94 DANTAS, Paulo Roberto de Figueiredo. Direito processual constitucional. 6a. ed. São Paulo: Atlas, 2015. p. 39.

$95 \quad$ LUCCA, Rodrigo Ramina de. Op. cit. p. 225.

96 COUTINHO SILVA, Ana de Lourdes. Motivação das decisões judiciais. São Paulo: Atlas, 2012. p. 160.

97 SILVA, Ovídio Batista da. Constituição e segurança jurídica. In: Constituição e segurança jurídica: direito adquirido, ato jurídico perfeito e coisa julgada - estudos em homenagem a José Paulo Sepúlveda Pertence. Carmem Lúcia Antunes Rocha (Coord.) Belo Horizonte: Fórum, 2005. p. 471. 
Revista Eletrônica de Direito Processual - REDP.

Rio de Janeiro. Ano 13. Volume 20. Número 2. Maio a Agosto de 2019

Periódico Quadrimestral da Pós-Graduação Stricto Sensu em Direito Processual da UERJ

Patrono: José Carlos Barbosa Moreira (in mem.). ISSN 1982-7636. pp. 125-158

www.redp.uerj.br

rejeitam-se os embargos de declaração por um motivo que serve para justificar qualquer outra decisão, qual seja: a suposta clareza da decisão e o "mero inconformismo da parte".

A título de exemplo, de decisões que devem ser combatidas, cita-se a seguinte: “em que pesem as alegações, não há omissão, obscuridade ou contradição, vez que a decisão embargada foi clara, coerente e objetivamente expressa em todos os pontos, do que se observa simples inconformismo do embargante com a conclusão da decisão" 98 .

Reforçando a ausência de mudança de postura apontada nos tribunais, nota-se, ainda após a vigência do NCPC, a continuidade da prática pelo Superior Tribunal de Justiça em proferir decisões de viés generalista, aplicável para qualquer caso, quando aprecia embargos declaratórios, sem proceder com a devida individualização do aventado pela parte $^{99100}$.

Em que pese a existência, desde a década de 1990, de um processo de reforma do Poder Judiciário brasileiro para se alinhar aos anseios do mercado globalizado, visando incentivar a celeridade, segurança jurídica e a eficiência da prestação jurisdicional, tais variáveis, isoladas dos demais compromissos constitucionais, esvaziam de conteúdo da atividade jurisdicional. O Judiciário deve ser o concretizador das promessas de índole

98 PIACINI NETO, Odasir. O caso das decisões com fundamentação precária — ou sem fundamentação. 2018. Disponível em: < https://www.conjur.com.br/2018-fev-04/odasir-piacini-netodecisoes-fundamentacao-precaria>. Acesso em: 01 fev. 2019.

99 "EMBARGOS DE DECLARAÇÃO NO AGRAVO INTERNO NO AGRAVO EM RECURSO ESPECIAL. REQUISITOS DO ART. 1.022 E INCISOS DO CPC DE 2015. OMISSÃO CONSTATADA. EMBARGOS DE DECLARAÇÃO ACOLHIDOS SEM EFEITOS MODIFICATIVOS.

1. Depreende-se do artigo 1.022, e seus incisos, do novo Código de Processo Civil que os embargos de declaração são cabíveis quando constar, na decisão recorrida, obscuridade, contradição, omissão em ponto sobre o qual deveria ter se pronunciado o julgador, ou até mesmo as condutas descritas no artigo 489, parágrafo $1^{\circ}$, que configurariam a carência de fundamentação válida. Não se prestam os aclaratórios ao simples reexame de questões já analisadas, com o intuito de meramente dar efeito modificativo ao recurso.[...] 3. Embargos de declaração acolhidos sem efeitos modificativos” (EDcl no AgInt no AREsp 1225288/DF, Rel. Ministro LUIS FELIPE SALOMÃO, QUARTA TURMA, julgado em 13/12/2018, DJe 19/12/2018).

100 "PROCESSO CIVIL E TRIBUTÁRIO. AGRAVO INTERNO NO AGRAVO EM RECURSO ESPECIAL. ENUNCIADO ADMINISTRATIVO N. 3/STJ. ARTIGOS 489 E 1.022, I e II, CPC/2015. NÃO CARACTERIZAÇÃO. MATERIAIS ADQUIRIDOS. USO DESTINADO ÀS ATIVIDADES NÃO AFETAS AO ESTABELECIMENTO. DIREITO AO CREDITAMENTO. IMPOSSIBILIDADE. PRECEDENTES. AGRAVO INTERNO NÃO PROVIDO. 1. Ausência de violação dos artigos 1.022, parágrafo único, incisos I e II, 489, $\S 1^{\circ}$, I e IV do CPC, pois o acórdão recorrido, conforme trecho colacionado no acórdão de origem, manifestou-se de forma expressa acerca dos pontos apontados como omissos. [...] 3. Agravo interno não provido" (AgInt no AREsp 1358361/RS, Rel. Ministro MAURO CAMPBELL MARQUES, SEGUNDA TURMA, julgado em 11/12/2018, DJe 14/12/2018). 
Revista Eletrônica de Direito Processual - REDP.

Rio de Janeiro. Ano 13. Volume 20. Número 2. Maio a Agosto de 2019

Periódico Quadrimestral da Pós-Graduação Stricto Sensu em Direito Processual da UERJ

Patrono: José Carlos Barbosa Moreira (in mem.). ISSN 1982-7636. pp. 125-158

www.redp.uerj.br

constitucional $^{101}$ e as técnicas processuais precisam se ajustar a implementação dos direitos assegurados pelo ordenamento jurídico.

Os argumentos são a expressão pública da reflexão e o bom juiz é aquele que consegue persuadir a comunidade jurídica a acolher os fundamentos de sua decisão, após analisar os todos os pontos de vista, para o caso concreto, subscrevendo tal solução para casos análogos ${ }^{102}$.

O Estado Democrático de Direito exige que os direitos sejam cumpridos, não podendo o dever constitucional de fundamentação (artigo 93, inciso IX, da CF), regulamentado pelo parágrafo primeiro do artigo 489 do CPC/2015, ser menosprezado ou diminuído. Assim, a ausência de fundamentações judiciais adequadas não é um mero capricho acadêmico, mas uma exigência jurídica para o bom funcionamento da cidadania e da democracia ${ }^{103}$.

Dessa forma, o Novo Código de Processo Civil concretizou as garantias consagradas na Constituição Federal: o caput e $\S 1$. $^{\circ}$ do artigo 489 do NCPC, ao regulamentar a noção de decisões judiciais não fundamentadas, trouxe um impotente reforço ao dever de motivação das decisões judiciais, previsto no artigo 93, inciso IX, da CF, buscando assegurar e dar maior plenitude a sua observância ${ }^{104}$.

\section{Conclusão}

O artigo 489, § $1^{\circ}$, do Código de Processo Civil de 2015, procura combater as decisões que: a) se limitam à indicação, à reprodução ou à paráfrase de ato normativo, sem explicar sua relação com a causa ou a questão decidida; b) empregam conceitos jurídicos indeterminados, sem explicar o motivo concreto de sua incidência no caso; c) invocam

ORLANDO OLIVEIRA, Lucas Paulo. O direito a favor da esperança: o uso dos precedentes para a efetivação da dignidade da pessoa humana. Dissertação (Mestrado) - Universidade Paranaense, Umuarama, 2018. p. 258.

102 CAMBI, Eduardo. Op. cit., p. 447.

103 STRECK. Lenio Luiz. Op. cit., p. 122.

104 GALVÃO; Danyelle da Silva; PEIXOTO JÚNIOR, Hélio; LOBO, Ricardo. O artigo 489 do Novo Código de Processo Civil (Lei 13.105/2015) e suas implicações no Direito Processual Penal. 2017. Revista

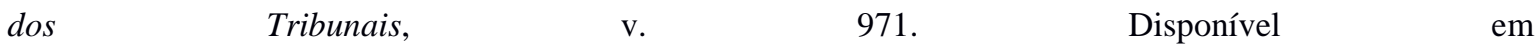
<http://www.mpsp.mp.br/portal/page/portal/documentacao_e_divulgacao/doc_biblioteca/bibli_servicos_prod utos/bibli_boletim/bibli_bol_2006/RTrib_n.971.13.PDF/>. Acesso em: 19 jan. 2019. 
motivos que se prestariam a justificar qualquer outra decisão; d) não enfrentam todos os argumentos deduzidos no processo capazes de, em tese, infirmar a conclusão adotada pelo julgador; e) se limitam a invocar precedente ou enunciado de súmula sem identificar seus fundamentos determinantes nem demonstrar que o caso sob julgamento se ajusta àqueles fundamentos; f) deixam de seguir enunciado de súmula, jurisprudência ou precedente invocado pela parte, sem demonstrar a existência de distinção no caso em julgamento ou a superação do entendimento.

A decisão judicial, ao violar o conteúdo do artigo $489, \S 1^{\circ}$, do $\mathrm{CPC} / 2015$, é nula e o ato judicial é inconstitucional, por afronta ao artigo 93, inciso IX, da Constituição Federal.

Nessa perspetiva, o Novo Código de Processo Civil, com o advento do artigo 489, § $1^{\circ}$, procura taxar de não fundamentada as decisões judiciais que descumprem a garantia constitucional do contraditório. Também, traz meios de combate às decisões não corretamente fundamentadas, ao prever no artigo 1022 o cabimento dos embargos de declaração contra estes atos. Porém, há forte resistência dos tribunais em aplicar o artigo 489 , $\S 1^{\circ}$, do $\mathrm{CPC} / 2015$, notadamente o Superior Tribunal de Justiça, que confere interpretação destoante da pretendida pelo legislador, principalmente no que tange ao inciso IV, do citado dispositivo, uma vez que continua com visão retrógrada de que o julgador não está obrigado a responder a todas as questões relevantes suscitadas pelas partes, quando já tenha encontrado motivo suficiente para proferir a decisão.

Portanto, cabe à doutrina o papel, desde logo, de indicar o norte correto a ser seguido pelos Tribunais. E, para se ter sucesso nessa empreitada, é importante a interpretação sistemática dos preceitos contidos nos artigos $5^{\circ}$, LV e 93, IX, da CF, juntamente com as regras presentes nos artigos $7^{\circ}, 10^{\circ}, 11^{\circ}$ e $489, \S 1^{\circ}$, do CPC/2015.

Diante do exposto, há evidente ilegalidade e inconstitucionalidade na negativa de aplicação integral do artigo 489, § $1^{\circ}$, do CPC/2015, quando, por meio de jurisprudências defensivas, principalmente do STJ, ofende-se o propósito do legislador e até a própria obrigatoriedade constitucional de fundamentação das decisões judiciais.

\section{REFERÊNCIAS}

AMARAL SANTOS, Moacyr. Primeiras Linhas de Direito Processual Civil. Vol. 3. 4a. ed. São Paulo: Max Limonad, 1973. 
ARAÚJO, Fábio Caldas de. Curso de Processo Civil: parte geral. São Paulo: Malheiros, 2016.

BRASIL. Constituição (1988). Constituição da República Federativa do Brasil. Diário Oficial [da] República Federativa do Brasil, Brasília, DF, 05 out. 1988. Disponível em: <http://www.planalto.gov.br/ccivil_03/constituicao/constituicao.htm>. Acesso em: 29 mar. 2017.

BRASIL, Código de Processo Civil. Diário Oficial [da] República Federativa do Brasil, Brasília, DF, 16 mar. 2015. Disponível em: <http://www.planalto.gov.br/ccivil_03/_ato2015-2018/2015/lei/113105.htm>. Acesso em: 12 mar. 2019.

BRASIL, Superior Tribunal de Justiça. Diário [da] Justiça Eletrônico Embargos de Declaração no Mandado de Segurança n ${ }^{\circ}$ 21.315/DF. Embargante: Paulo Rodrigues Vieira. Embargado: União Federal. Relatora: Ministra Diva Malerbi. Disponível em: $<$ https://ww2.stj.jus.br/processo/revista/documento/mediado/?componente=ATC\&se quencial $=61426619 \&$ num_registro $=201402570569 \&$ data $=20160615 \&$ tipo $=51 \&$ for mato=PDF $>$. Acesso em: 22 ago. 2017.

BRASIL. Superior Tribunal de Justiça. Recurso especial $\mathrm{n}^{\mathrm{o}} 1.676 .573$ - PE (2017/0133468-0). Partes litigantes Ministério Público do Estado de Pernambuco e Fernando Antônio de Sá de Oliveira Filho. Relator Ministro Herman Benjamin. Segunda turma. Julgado em 21. nov. 2017.Diário da Justiça Eletrônico [da] República Federativa do Brasil, 21 nov. 2017. Disponível em: $<$ https://ww2.stj.jus.br/processo/revista/documento/mediado/?componente=ITA\&seq uencial $=1636614 \&$ num_registro $=201701334680 \&$ data $=20171219 \&$ formato $=P D F>$. Acesso em: 29 set. 2018.

BRASIL. Superior Tribunal de Justiça. Agravo interno no agravo no recurso especial $\mathrm{n}^{\circ}$ 1.310.033 - SP (2018/0144380-6). Partes litigantes Polimold Industrial S/A e Fazenda Nacional. Relator Ministro Francisco Falcão. Segunda turma. Julgado em 13. nov. 2018. .Diário da Justiça Eletrônico [da] República Federativa do Brasil, 21 nov. 2018.

Disponível em: $<$ https://ww2.stj.jus.br/processo/revista/documento/mediado/?componente=ITA \&sequencial $=1770078 \&$ num_registro $=201801443806 \&$ data $=20181121 \&$ formato $=P$ DF>.Acesso em: 29 set. 2018. 
BRASIL. Superior Tribunal de Justiça. Diário [da] Justiça Eletrônico Embargos de

Declaração no agravo no recurso especial no 1.225 .288 - DF (2017/0330674-9).

Embargante: Auto Shopping Derivados de Petróleo Ltda. - em recuperação judicial. Embargado: Ministério Público do Distrito Federal e Territórios. Relator: Ministro Luis Felipe Salomão. Disponível em: $<$ https://ww2.stj.jus.br/processo/revista/documento/mediado/?componente=ITA\&seq uencial $=1781830 \&$ num_registro $=201703306749 \&$ data $=20181219 \&$ formato $=P D F>$. Acesso em: 02 jan. 2019.

BRASIL. Superior Tribunal de Justiça. Diário [da] Justiça Eletrônico Embargos de Declaração no agravo interno no recurso especial no 1.358 .361 - RS (2018/02285715). Agravante: Companhia Zaffari Comércio e Indústria. Agravado: Estado do Rio Grande do Sul. Relator: Ministro Mauro Campbell Marques. Disponível em: $<$ https://ww2.stj.jus.br/processo/revista/documento/mediado/?componente=ITA\&seq uencial $=1783853 \&$ num_registro $=201802285715 \&$ data $=20181214 \&$ formato $=P D F>$. Acesso em: 12 jan. 2019.

BULOS, Uadi Lammêgo. Constituição Federal anotada. 10a. ed. São Paulo: Saraiva, 2012.

CÂMARA. Alexandre Freitas. O novo processo civil brasileiro. 3a. ed. São Paulo: Atlas, 2017.

CANOTILHO. José Joaquim Gomes. et al. (Coord.). Comentários à Constituição do Brasil. São Paulo: Almedina, 2013.

CANOTILHO. José Joaquim Gomes. Constituição Dirigente e Vinculação do Legislador. Coimbra: Coimbra, 2001.

CAMBI, Eduardo. Neoconstitucionalismo e neoprocessualismo: Direitos fundamentais, políticas públicas e protagonismo judiciário. 2a. ed. São Paulo: Almedina, 2018.

CAMBI, Eduardo; DOTTI, Rogeria; PINHEIRO, Paulo Eduardo D`arce; KOZIKOSKI, Sandro Marcelo. Curso de processo civil completo. São Paulo: Revista dos Tribunais, 2017.

CERQUEIRA. Vinícius Nascimento. Fundamentos da decisão no novo CPC: $O$ contraditório forte e os precedentes. Jundiaí: Paco Editorial: 2014.

CUNHA, José Sebastião Fagundes (Coord. geral); BOCHENEK, Antonio Cesar; CAMBI, Eduardo (Coord). Código de Processo Civil comentado. São Paulo: Revista dos 
Tribunais, 2016.

COUTINHO SILVA, Ana de Lourdes. Motivação das decisões judiciais. São Paulo: Atlas, 2012.

DANTAS, Paulo Roberto de Figueiredo. Direito processual constitucional. 6a. ed. São Paulo: Atlas, 2015.

DINAMARCO. Cândido Rangel. A instrumentalidade do processo. 12a. ed. São Paulo: Malheiros Editores, 2005.

DIDIER JÚNIOR, Fredie; CARNEIRO DA CUNHA, Leonardo. Curso de direito processual civil. v. 3. 13. ed. Salvador: Juspodivm, 2016.

DIDIER JÚNIOR, Fredie; BRAGA, Paulo Sarno; OLIVEIRA, Rafael Alexandria de. Curso de direito processual civil. v. 2. 10. ed. Salvador: Juspodivm, 2015.

DONIZETTI, Elpídio. Novo Código de Processo Civil comentado. 2. ed. São Paulo: Atlas, 2017.

DONIZETTI, Elpídio. Curso didático de direito processo civil. 17. ed. São Paulo: Atlas, 2013.

FLUMIGNAN, Silvano José Gomes. Novo CPC exige conceito técnico do que significa precedente. 2015. Disponível em <https://www.conjur.com.br/2015-jul-11/cpcexige-conceito-tecnico-significa-precedente>. Acesso em: 22 jan. 2019.

GALVÃO; Danyelle da Silva; Hélio Peixoto JUNIOR; Ricardo LOBO. O artigo 489 do Novo Código de Processo Civil (Lei 13.105/2015) e suas implicações no Direito Processual Penal. 2017. Revista dos Tribunais, v. 971. Disponível em <http://www.mpsp.mp.br/portal/page/portal/documentacao_e_divulgacao/doc_biblio teca/bibli_servicos_produtos/bibli_boletim/bibli_bol_2006/RTrib_n.971.13.PDF/>. Acesso em: 19 jan. 2019.

GIORGI JÚNIOR. Romulo Ponticelli. Jurisdição Constitucional e o Código de Processo Civil: sincronia, racionalidade, interpretação e segurança jurídica. São Paulo: Revista dos Tribunais, 2017.

GOULART, Cristiano. Os elementos essenciais da sentença no novo CPC 2015. A obrigatoriedade da correta fundamentação da sentença. 2015. Disponível em <https://cristianogoulart.jusbrasil.com.br/artigos/209688771/os-elementosessenciaisda-sentenca-no-novo-cpc-2015>. Acesso em: 01 jan. 2019.

HESSE, Konrad. Elementos de Direito Constitucional da República Federal da Alemanha. 
Tradução de Luís Afonso Heck. 20. ed. Porto Alegre: Sérgio Antônio Fabris Editor, 1998

JACINTHO, Igor. A decisão fundamentada do CPC vs O recente julgado do STJ. 2015.

Disponível em < https://ighorf.jusbrasil.com.br/artigos/365177368/a-decisaofundame ntada-do-cpc-vs-o-recente-julgado-do-stj>. Acesso em: 01 jan. 2019.

KOZIKOSKI, Sandro Marcelo. Sistema Recursal - CPC 2015: em conformidade com a Lei 13.256/2016. Salvador: Juspodivm, 2016.

KREBS. Hélio Ricardo Diniz. Sistema de precedentes e direitos fundamentais. São Paulo: Revista dos Tribunais, 2015.

LUCCA, Rodrigo Ramina de. O dever de motivação das decisões judiciais: Estado de direito, segurança jurídica e teoria dos precedentes. 2. ed. Salvador: Juspodivm, 2016.

MARCACINI. Augusto Tavares Rosa. As inovações do CPC/2015. Da propositura da ação até a sentença. São Paulo: A. Marcacini, 2016.

MARINONI, Luiz Guilherme. ARENHART. Sérgio Cruz; MITIDIERO, Daniel. Curso de Processo Civil. Tutela dos direitos mediante procedimento comum. 3. ed. vol. 2. Revista dos Tribunais: São Paulo, 2017.

MEDINA. José Miguel Garcia. Curso de direito processual civil moderno. 3 ed. São Paulo: Revista dos Tribunais, 2017.

MOTTA, Cristina Reindolff da. A motivação das decisões cíveis como condição de possibilidade para a resposta correta/adequada. Porto Alegre: Livraria do Advogado Editora, 2012.

NERY JÚNIOR. Nelson. Princípios do processo civil na Constituição Federal. 7. ed. Sao Paulo: Revista dos Tribunais, 2002.

NEVES, Daniel Amorim Assumpção. Novo CPC para advogados. 2. ed. São Paulo: Método, 2018.

ORLANDO DE OLIVEIRA, Lucas Paulo. O direito a favor da esperança: o uso dos precedentes para a efetivação da dignidade da pessoa humana. Dissertação (Mestrado) - Universidade Paranaense, Umuarama, 2018.

PAULA, Jônatas Luiz Moreira de. Curso de processo civil: processo de conhecimento no novo CPC. 2 ed. Belo Horizonte: D’Plácido, 2016.

PIACINI NETO, Odasir. O caso das decisões com fundamentação precária — ou sem 
fundamentação. 2018. Disponível em: < https://www.conjur.com.br/2018-fev-

04/odasir-piacini-neto-decisoes-fundamentacao-precaria>. Acesso em: 01 fev. 2019.

RODRIGUES WAMBIER Luiz; TALAMINI Eduardo. Curso avançado de processo civil:

cognição jurisdicional, processo comum de conhecimento e tutela provisória. v. 2. 5.

ed. São Paulo: Revista dos Tribunais, 2016.

RODRIGUES WAMBIER Luiz; TALAMINI Eduardo. Curso Avançado de Processo Civil. v.1. 13 ed. São Paulo: Revista dos Tribunais, 2013.

SCHMITZ, Leonard Ziesemer. Fundamentação das decisões judiciais: a crise na construção de respostas no processo civil. São Paulo: Revista dos Tribunais, 2015.

SILVA, Ovídio Batista da. Constituição e segurança jurídica. In: Constituição e segurança jurídica: direito adquirido, ato jurídico perfeito e coisa julgada - estudos em homenagem a José Paulo Sepúlveda Pertence. Carmem Lúcia Antunes Rocha (Coord.) Belo Horizonte: Fórum, 2005.

STRECK. Lenio Luiz. Verdade e consenso. Constituição, hermenêutica e teorias discursivas. 6. ed. São Paulo: Saraiva, 2017.

STRECK. Lenio Luiz. O que é isto - decido conforme minha consciência? 6. ed. Porto Alegre: Livraria do Advogado, 2017.

VASCONCELLOS, Marcos de; ROVER, Tadeu. Juízes pedem veto a artigo que traz regras para fundamentação de decisões. 2015. Disponível em <https://www.conjur.com.br/2015-mar-04/juizes-pedem-veto-artigo-cpc-exigefundamentacao>. Acesso em: 25 jan. 2019.

TARUFFO, Michele. Uma simples verdade: O juiz e a construção dos fatos. Tradução Vitor de Paula Ramos. São Paulo: Marcial Pons, 2016. 